\title{
Efficiency Enhancement of Perovskite Solar Cells by fabricating as-prepared film before sequential spin-coating procedure
}

\author{
JiajiaJiang ${ }^{a}$, HaijunTao ${ }^{\mathrm{a}, \mathrm{b}_{*}}$, Shanlong Chen ${ }^{\mathrm{a}}$, Bin Tan ${ }^{\mathrm{a}}$, Ning Zhou ${ }^{\mathrm{c}}$, LuminZhu ${ }^{\mathrm{a}}$, Yuan Zhao ${ }^{\mathrm{a}}$, \\ YuqiaoWang ${ }^{d}$ and JieTao ${ }^{a}$ \\ ${ }^{a}$ Jiangsu Key Laboratory of Materials and Technology for Energy Conversion, \\ College of material science and technology, Nanjing University of Aeronautics and \\ Astronautics, Nanjing 211100, PR China \\ ${ }^{\mathrm{b}}$ Jiangsu Collaborative Innovation Center of Photovolatic Science and Engineering, \\ Changzhou University, Changzhou 213164, Jiangsu, PR China \\ ${ }^{c}$ Shanghai Electrochemical Energy Devices Research Center, School of Chemistry \\ and Chemical Engineering, Shanghai Jiao Tong University, Shanghai 200240, PR \\ China \\ ${ }^{d}$ Jiangsu Optoelectronic Functional Materials and Engineering Laboratory, School \\ of Chemistry and Chemical Engineering, Southeast University, Nanjing 211189, PR \\ China \\ *Corresponding author. E-mail address:taohaijun@nuaa.edu.cn
}

\begin{abstract}
Sequential spin-coating procedure is a widely adopted strategy to prepare $\mathrm{CH}_{3} \mathrm{NH}_{3} \mathrm{PbI}_{3}$ on mesostructured $\mathrm{TiO}_{2}$ electrode for organolead halide perovskite-based solar cells. However, this method suffers from the rough surface and excessively residual $\mathrm{PbI}_{2}$ in the resulting perovskite film, deteriorating the device performance seriously. Herein, a facial modified sequential solution deposition method, by introducing an as-prepared $\mathrm{CH}_{3} \mathrm{NH}_{3} \mathrm{PbI}_{3}$ and $\mathrm{PbI}_{2}$ film before the traditional two-step process, was proposed to fabricate the perovskite-based solar cell with smooth morphology and trace amount of remaining $\mathrm{PbI}_{2}$. The optimal as-prepared film introduced improves the efficiency of $\mathrm{CH}_{3} \mathrm{NH}_{3} \mathrm{PbI}_{3}$ solar cells from $9.11 \%$ to $11.16 \%$. The enhancement of device performance can be attributed to the increased light absorption ability and decreased recombination rate of carriers in $\mathrm{CH}_{3} \mathrm{NH}_{3} \mathrm{PbI}_{3}$ absorber.
\end{abstract}

Keywords: $\mathrm{CH}_{3} \mathrm{NH}_{3} \mathrm{PbI}_{3}$;perovskite-based solar cells;residual $\mathrm{PbI}_{2} ;$ modified sequentialdeposition method;smooth morphology 


\section{Introduction}

Organomeatal halide perovskite-based solar cells have recently attracted much attention because of their excellent photoelectric properties, such as tuneable optical band gaps, high light absorption coefficients, ultrafast charge generation, high carrier mobility, long charge carrier diffusion length and so on. ${ }^{1-3}$ In 2009 , together with iodide liquid electrolyte, $\mathrm{CH}_{3} \mathrm{NH}_{3} \mathrm{PbI}_{3}$ and $\mathrm{CH}_{3} \mathrm{NH}_{3} \mathrm{PbBr}_{3}$ were employed to fabricate sensitized solar cells by Miyasaka, ${ }^{4}$ and a power conversion efficiency (PCE) beyond $6 \%$ was obtained. But organometal halide perovskite is an ionic crystal, and it easily dissolves in iodic electrolyte. ${ }^{5}$ To solve the instability problem, Park first introduced spiro-OMeTAD as hole transport materials (HTM) to substitute the liquid iodide electrolyte, ${ }^{6}$ and PCE exceeding 9\% was achieved. Since then, researches on perovskite solar cells have been triggered, including synthesizing new materials, discovering device mechanisms and developing different fabrication methods. ${ }^{7-10}$

There have been many technologies developed to prepare organolead halide perovskite $\mathrm{MAPbX}_{3}\left(\mathrm{MA}=\mathrm{CH}_{3} \mathrm{NH}_{3}, \mathrm{X}=\mathrm{I}, \mathrm{Cl}, \mathrm{Br}\right)$ thin films, such as chemical solution deposition methods, ${ }^{6,11-12}$ vapor-phasedeposition ${ }^{13}$ and vapour-assisted solution processes. ${ }^{14}$ The most adopted process is solution deposition method which is clarified to one-step and two-step deposition procedure. In the one-step method, the precursors (e.g. MAI and $\mathrm{PbI}_{2}$ ) are dissolved together in a polar solvent, such as dimethylformamide (DMF), and spin-coated on mesoporous $\mathrm{TiO}_{2}$-coated substrate. After then it is heated at $75-150{ }^{\circ} \mathrm{C}$ to evaporate the polar solvent. ${ }^{6}$ However, there is a serious drawback during this process. Poor film formation (incomplete surface coverage with pinholes) induced by extensive crystallization caused by solvent evaporation and strong ionic interaction between $\mathrm{MAI}$ and $\mathrm{PbI}_{2}$, limit the efficiency of devices. ${ }^{15}$ To get better perovskite morphology and higher PCE, two-step sequential deposition method was put forward by Grätzel. ${ }^{11} \mathrm{PbI}_{2}$ crystal is first introduced from solution into a nanoporous $\mathrm{TiO}_{2}$ film and subsequently transformed into the $\mathrm{MAPbI}_{3}$ by exposing it to a solution of $\mathrm{CH}_{3} \mathrm{NH}_{3} \mathrm{I}$. The perovskite morphology can be tuneable by control the morphology of $\mathrm{PbI}_{2}$ crystal, and the highest PCE of $15 \%$ was achieved. 
However, the average PCE was as low as $12 \%$ and the standard deviation was as large as \pm 2.0 . Thus, a reproducible and efficient way is required. Park proposed a method called two-step sequential spin-coating procedure and $\mathrm{MAI}_{3}$ solution spin-coated on $\mathrm{PbI}_{2}$ film was the main difference from the former process. ${ }^{12}$ The size of the $\mathrm{MAPbI}_{3}$ crystal could be controlled by the $\mathrm{CH}_{3} \mathrm{NH}_{3} \mathrm{I}$ solution concentration and an average PCE exceeding $16 \%$ with small standard deviation (less than 0.4) was achieved. Nevertheless, for the rapid reaction between $\mathrm{PbI}_{2}$ and $\mathrm{CH}_{3} \mathrm{NH}_{3} \mathrm{I}$, the quick formation of the upper perovskite film retard the inner $\mathrm{PbI}_{2}$ to react with $\mathrm{CH}_{3} \mathrm{NH}_{3} \mathrm{I}$, leading to the remnant $\mathrm{pbI}_{2}$ exists between $\mathrm{TiO}_{2}$ and $\mathrm{MAPbI}_{3} \cdot{ }^{15}$ It is generally acknowledged that the excess residual $\mathrm{PbI}_{2}$ will block the electron injection from perovskite to $\mathrm{TiO}_{2}{ }^{16}$ However, the trace amount of $\mathrm{PbI}_{2}$ in perovskite film can retard the charge recombination and benefit to the device performance. ${ }^{17}$ Apparently, it is necessary to decrease the amounts of $\mathrm{PbI}_{2}$ in perovskite film, so as to extend perovskite solar cell performance. Several modified strategies have been employed to meet this goal. Xu controled the reaction temperature and $\mathrm{CH}_{3} \mathrm{NH}_{3} \mathrm{I}$ solution concentration, ${ }^{18}$ Huang used $\mathrm{CH}_{3} \mathrm{NH}_{3} \mathrm{I}$ as additive in $\mathrm{PbI}_{2}$ solution ${ }^{19}$ and Kanatzidis increased the $\mathrm{PbI}_{2}$-coated film dipping time. ${ }^{17}$ Although they have tackled the $\mathrm{PbI}_{2}$ issue, there is another problem existing in the two-step sequential spin-coating process, the fast crystallization tendency of the perovskite films leads to rough surface morphologies which could introduce shunts into the solar cells. It is necessary to develop a more reliable approach to acquire $\mathrm{MAPbI}_{3}$ film with less remnant $\mathrm{PbI}_{2}$ and smooth surface.

In this paper, a feasible pre-treatment was proposed to solve the problems. Before the two-step spin-coating procedure, we first dripped different concentration DMF solution including $\mathrm{PbI}_{2}$ and $\mathrm{CH}_{3} \mathrm{NH}_{3} \mathrm{I}$ onTiO丶 2 -coated layer to acquire the as-prepared film. The final crystallization and surface morphology of $\mathrm{CH}_{3} \mathrm{NH}_{3} \mathrm{PbI}_{3}$ was very sensitive to the as-prepared film. All the samples with suitable as-prepared film had a decrease of remnant $\mathrm{PbI}_{2}$ and smooth surface. Interestingly, light absorption capacity of these devices was improved. Compared with the untreated sample, PCE for optimal treated-device was enhanced from $9.11 \%$ to $11.06 \%$. The improved device 
performance can be owing to the increase of short-circuit current $\left(\mathrm{J}_{\mathrm{SC}}\right)$, which is proved by light harvest efficiency (LHE) and photoluminescence (PL) spectra.

\section{Experimental section}

\subsection{Materials}

Lead iodide $\mathrm{PbI}_{2} \quad$ (99\%), N,N-dimethylformide (DMF, 99\%), 4-tert-butylpyridine(96\%), lithium bis (trifluoromethanesulfonyl) imide (Li-TFSI), acetonitrile (99.8\%) and chlorobenzene (99.8\%) were purchased from Sigma-Aldrich. Isopropanol (99.8\%) and titanium isopropoxide were from Aladdin. $\mathrm{TiCl}_{4}$ and hydrochloric acid were obtained from Shanghai Chemical Agent Ltd., China (Analysispurity grade) and 2,2',7,7' -tetrakis(N,N-di-p-methoxyphenylamine)-9,9-spirobifluorene(spiro-MeOTA D)was from Luminescence Technology Corp., Taiwan. All the chemicals were directly used without further purification.

\subsection{Synthesis of $\mathrm{CH}_{3} \mathrm{NH}_{3} \mathrm{I}$ crystal and $\mathrm{TiO}_{2}$ block layer precursor solution}

$\mathrm{CH}_{3} \mathrm{NH}_{3} \mathrm{I}$ was synthesized by reaction of $27.8 \mathrm{~mL}$ of $\mathrm{CH}_{3} \mathrm{NH}_{2}$ (40 wt $\%$ in methanol, TCI) with $30 \mathrm{~mL}$ of $\mathrm{HI}$ (57 wt\% in water, Aldrich) in a round bottomed flask under vigorous stirring for $2 \mathrm{~h}$ in ice bath. The precipitated $\mathrm{CH}_{3} \mathrm{NH}_{3} \mathrm{I}$ was collected using rotary evaporator at $50^{\circ} \mathrm{C}$ for $1 \mathrm{~h}$, washed with diethyl ether several times and finally dried at $60{ }^{\circ} \mathrm{C}$ in vacuum for $24 \mathrm{~h}$.

The $\mathrm{TiO}_{2}$ block layer precursor solution was synthesized by the available process as reported in literature. First, titanium isopropoxide $(369 \mu \mathrm{l})$ was diluted in isopropanol $(2.53 \mathrm{ml})$ at $0.46 \mathrm{M}$. Meanwhile, a $2 \mathrm{M} \mathrm{HCl}$ solution $(35 \mu \mathrm{l})$ was diluted down with isopropanol $(2.53 \mathrm{ml})$ to achieve a $0.026 \mathrm{M}$ concentration. At last, the acid-containing solution was added dropwise to the titanium precursor solution under heavy stirring. The solution was filtered with a PTFE filter with $0.2 \mathrm{~mm}$ pore size before use $\mathrm{s}^{20}$.

\subsection{Solar cell fabrication}

Solar cells were fabricated in dry box with humidity inside being about $15 \%$. The patterned FTO coated glass substrates (Nippon, thickness: $2.2 \mathrm{~mm}$, sheet resistance 14 $\Omega^{-2}$ ) were cleaned with deionized water, ethanol and acetone successively and then 
subjected to an ozone-ultraviolet treatment for $15 \mathrm{~min}$. Then the FTO substrates were coated with a compact $\mathrm{TiO}_{2}$ layer deposited by spin coating the $\mathrm{TiO}_{2}$ precursor solution at 2,000 r.p.m for $60 \mathrm{~s}$ and were subsequently under annealing at $500{ }^{\circ} \mathrm{C}$ for $30 \mathrm{~min}$. The mesoporous $\mathrm{TiO}_{2}$ layer composed of 25 -nm-sized particles was obtained by spin coating a commercial $\mathrm{TiO}_{2}$ paste (Dyesol 18NRT, Dyesol), which was diluted in ethanol (1:7, weight ratio), at 3,000 r.p.m for 30 s. Followed by heating at $325{ }^{\circ} \mathrm{C}$ for $5 \mathrm{~min}, 375{ }^{\circ} \mathrm{C}$ for $5 \mathrm{~min}, 450{ }^{\circ} \mathrm{C}$ for $15 \mathrm{~min}$, and finally at $500{ }^{\circ} \mathrm{C}$ for $15 \mathrm{~min}$ respectively. The mesoporous $\mathrm{TiO}_{2}$ film was then dipped into $20 \mathrm{mM} \mathrm{TiCl} 4$ aqueous solution for $15 \mathrm{~min}$ at $70{ }^{\circ} \mathrm{C}$ and washed with deionized water and alcohol, with sintered at $500{ }^{\circ} \mathrm{C}$ for $30 \mathrm{~min}$ subsequently. Before the two-step spin-coating procedure, the $\mathrm{TiO}_{2}$-coated substrates were heated at $100{ }^{\circ} \mathrm{C}$ for $15 \mathrm{~min}$ and then spin-coated with different concentrations of DMF solution (30 $\mu \mathrm{l})$ containing $\mathrm{PbI}_{2}$ and $\mathrm{CH}_{3} \mathrm{NH}_{3} \mathrm{I}$ at 3,000 r.p.m for 30 s. The molar ratio of $\mathrm{PbI}_{2}$ and $\mathrm{CH}_{3} \mathrm{NH}_{3} \mathrm{I}$ was 1:1.The molar concentrations of $\mathrm{PbI}_{2}$ in $\mathrm{DMF}$ were $0.1 \mathrm{M}, 0.2 \mathrm{M}, 0.3 \mathrm{M}$ and $0.4 \mathrm{M}$, respectively. For the DMF solution of $0.1 \mathrm{M}, 46 \mathrm{mg} \mathrm{PbI}_{2}$ and $15.9 \mathrm{mg} \mathrm{CH}_{3} \mathrm{NH}_{3} \mathrm{I}$ were resolved in $1 \mathrm{ml}$ DMF under stirring at $70{ }^{\circ} \mathrm{C}$. The corresponding films pre-treated by different concentrations of DMF solution could be defined as $\mathrm{x}$-prefilm $(\mathrm{x}=0.1,0.2$, 0.3 , and 0.4 ). After then, $\mathrm{CH}_{3} \mathrm{NH}_{3} \mathrm{PbI}_{3}$ was formed by two-step spin-coating method. $\mathrm{PbI}_{2}$ solution $(1 \mathrm{M})$ was prepared by dissolving $462 \mathrm{mg} \mathrm{PbI}_{2}$ in $1 \mathrm{ml} \mathrm{DMF}$ under stirring at $70{ }^{\circ} \mathrm{C}$. $\mathrm{PbI}_{2}$ solution $(20 \mu \mathrm{l})$ was spin-coated on the pre-treated film at 6,000 r.p.m for $10 \mathrm{~s}$ (without loading time), the formed film can be named as $\mathrm{PbI}_{2}$-xprefilm. After spinning, the film was dried in air at $40{ }^{\circ} \mathrm{C}$ for 3 min and then at $100{ }^{\circ} \mathrm{C}$ for 5 min. After the substrate cooling down to room temperature, $200 \mu \mathrm{l}$ of $0.038 \mathrm{M}$ (6 mg $\left.\mathrm{ml}^{-1}\right) \mathrm{CH}_{3} \mathrm{NH}_{3} \mathrm{I}$ solution in isopropanol was loaded on the $\mathrm{PbI}_{2}$-coated substrate for 20 s (loading time), which was spun at 6,000 r.p.m for $10 \mathrm{~s}$ and dried at $100{ }^{\circ} \mathrm{C}$ for 10 min. The formed perovskite film with pre-treatment was labelled as $\mathrm{MAPbI}_{3}$-xprefilm.After the substrate cooling down to room temperature, a hole transport layer solution was spin-coated at 2000 r.p.m for $30 \mathrm{~s}$, in which $1 \mathrm{~mL}$ spiro-OMeTAD/chlorobenzene $(72.3 \mathrm{mg} / \mathrm{mL})$ solution was employed with addition of $18 \mathrm{~mL} \mathrm{Li}$-TFSI/acetonitrile $(520 \mathrm{mg} / \mathrm{mL})$, and $29 \mathrm{~mL}$ 4-tert-butylpyridine. Devices 
were then placed overnight in dry air for the spiro-OMeTAD to oxidize completely. Finally, $80 \mathrm{~nm}$ gold electrodes were ion sputtered under vacuum of $\sim 10^{-6} \mathrm{Torr}$, at a rate of $\sim 0.07 \mathrm{~nm}^{-1}$, to complete the devices. The active area of the cell was approximately $0.15 \mathrm{~cm}^{2}$.

\subsection{Characterization and measurement}

$\mathrm{X}$-ray diffraction (XRD) was performed on a X-ray diffractometer (D8-Advance, Bruker, Germany) using $\mathrm{Cu}$ Ka radiation $(\lambda=1.5406 \AA)$ at step size/time of $0.06 \%$. The surface and cross-sectional morphology were observed using a field emission scanning electron microscope (FE-SEM, HITACHI SU-4800). Steady-state photoluminescence spectroscopy (PL) measurements were acquired using an Edinburgh Instruments FLS920 fluorescence spectrometer with an excitation wavelength of $460 \mathrm{~nm}$. The absorption spectra of the perovskite coated films were measured by using a Cary 500 UV-vis-NIR Spectrophotometer. The current density-voltage $(\mathrm{J}-\mathrm{V})$ measurements were conducted under simulated AM $1.5 \mathrm{G}$ sunlight of $100 \mathrm{~mW} / \mathrm{cm}^{2}$ using an AM $1.5 \mathrm{G}$ type filter (Newport, USA). The light intensity was adjusted by using a standard Si cell. J-V curves were recorded with a Keithley model 2400 digital source meter at room temperature in the ambient air with humidity of 40-60\%. A typical active area of $0.15 \mathrm{~cm}^{2}$ was confined using a non-reflective mask for the J-V measurements.

\section{Results and Discussions}

The modified two-step procedure is depicted schematically in Fig. 1. Firstly, the mixed DMF solution containing $\mathrm{PbI}_{2}$ and $\mathrm{CH}_{3} \mathrm{NH}_{3} \mathrm{I}$ (MAI) was spin-coated on heated $\mathrm{TiO}_{2}$-coated film, and the $\mathrm{CH}_{3} \mathrm{NH}_{3} \mathrm{PbI}_{3}\left(\mathrm{MAPbI}_{3}\right)$ and $\mathrm{PbI}_{2}$ compound film was formed. Secondly, the $\mathrm{MAPbI}_{3}$ was dissolved by dipping a $\mathrm{PbI}_{2}$ solution on the pre-treated film above, in order to acquire the high crystalline of $\mathrm{PbI}_{2}$ and keep tiny MAI preserved in the film. The tiny reserved MAI promote the inner $\mathrm{PbI}_{2}$ converting to $\mathrm{MAPbI}_{3}$. At last, $\mathrm{MAPbI}_{3}$ with low remnant $\mathrm{PbI}_{2}$ was obtained by loading MAI solution onto $\mathrm{PbI}_{2}$-xprefilm. The phenomenon of low remnant $\mathrm{PbI}_{2}$ may be ascribed from the interaction between the initial $\mathrm{MAI}$ and $\mathrm{PbI}_{2}$ in solution. The smooth morphology of $\mathrm{MAPbI}_{3}$ film was achieved through adjusting the concentrations of 
mixed DMF solution.

In our modified method, the mixed DMF solution containing $\mathrm{PbI}_{2}$ and MAI is deposited on substrate to form the pre-film before the first step. Interestingly, there are more and more crystals covering on the surface of the substrate with the mixed DMF solution concentration increasing, as shown in Fig. S1. The crystals are indexed as the mixed structure of $\mathrm{MAPbI}_{3}$ and $\mathrm{PbI}_{2}$, which can be confirmed by the XRD analysis later. The pre-film contributes to a non-pinhole $\mathrm{PbI}_{2}$ film, whereas grate quantities of pin-holes are found in $\mathrm{PbI}_{2}$ film which is prepared by tradition procedure. As shown in the Fig. $\mathrm{S} 2, \mathrm{PbI}_{2}$ film gradually becomes compact from $\mathrm{PbI}_{2}-0.1$ prefilm to $\mathrm{PbI}_{2}-0.4$ prefilm sample.

Fig. 2 shows the surfaces and cross sections of the corresponding $\mathrm{MAPbI}_{3}$ films, which is formed by spin-coating $\mathrm{MAI}$ on the $\mathrm{PbI}_{2}$-xprefilm, denoted as $\mathrm{MAPbI}_{3}$-xprefilm ( $\mathrm{x}=0,0.1,0.2,0.3$ and 0.4$)$. As seen in all the pre-treated samples, $\mathrm{MAPbI}_{3}$ film is sensitive to the $\mathrm{PbI}_{2}$-xprefilm. For $\mathrm{MAPbI}_{3}-0.2$ prefilm, it is apparently noticed that the roughness is decreased, and similar perovskite crystals spread uniformly on the $\mathrm{TiO}_{2}$ substrate in Fig. 2b. However, perovskite grains of different sizes mix together and arrange disorderly for $\mathrm{MAPbI}_{3}-0$ prefilm. And the cross-section view of Fig. 2c and Fig. 2d, directly indicates that the $\mathrm{MAPbI}_{3}$ film without x-prefilm is rougher than $\mathrm{MAPbI}_{3}-0.2$ prefilm. The reason may be ascribed to the MAI solution penetrating into the hole of $\mathrm{PbI}_{2}$ film, leading to the simultaneous reaction on surface and inside of the $\mathrm{PbI}_{2}$ film. And the perovskite crystal grows at random, as $\mathrm{MAPbI}_{3}$ crystal corner and the gap between adjacent crystals can be seen in Fig. 2a clearly. In Seigo Ito's study, a smooth perovskite layer on mesoporous $\mathrm{TiO}_{2}$ can enhance the shunt resistance of cell and would be able to block the short circuit between $\mathrm{TiO}_{2}$ and spiro-OMeTAD. ${ }^{21-22}$ In addition to the difference of surface roughness, the perovskite layer thickness is varied. $\mathrm{MAPbI}_{3}-0$ prefilm is about $460 \mathrm{~nm}$, and $\mathrm{MAPbI}_{3}-0.2$ prefilm is about $200 \mathrm{~nm}$. According to Xing's research, the electron-hole diffusion length is about 100 nanometres in solution processed $\mathrm{MAPbI}_{3}{ }^{23}$ The perovskite layer with excess thickness may interfere with the electron injection into $\mathrm{TiO}_{2}{ }^{24}$

Nevertheless, the pin-holes are appearing on perovskite film for $\mathrm{MAPbI}_{3}-0.4$ prefilm 
sample. As shown in the high magnification in Fig. 2f, the $\mathrm{TiO}_{2}$ substrate can be seen clearly. The light-generated electron and hole can recombine easily before collection, due to the direct contact between $\mathrm{TiO}_{2}$ and spiro-OMeTAD. ${ }^{25}$ It may be the main factor for worsening perovskite solar cell performance of $\mathrm{MAPbI}_{3}-0.3$ prefilm and $\mathrm{MAPbI}_{3}-0.4$ prefilm. Through controlling the roughness, thickness, and coverage of $\mathrm{MAPbI}_{3}$ film, the best photovoltaic device based on $\mathrm{MAPbI}_{3}-0.2$ prefilm is obtained. $\mathrm{XRD}$ analysis was conducted to verify the phase composition of the x-prefim, $\mathrm{PbI}_{2}$-xprefilm and the final $\mathrm{MAPbI}_{3}$ layer on mesoporous $\mathrm{TiO}_{2}$ films. As seen in Fig. 3a, $\mathrm{MAPbI}_{3}$ and $\mathrm{PbI}_{2}$ both exits in the x-prefilm. $\mathrm{MAPbI}_{3}$ is polar tetragonal material at room temperature, and the $\mathrm{MAPbI}_{3}$ films usually demonstrate the preferred orientation of (110) peak at $14.82^{\mathrm{o}}{ }^{26}$ And the $\mathrm{PbI}_{2}$ can be easily certified via the (001) at $12.56^{\mathrm{o}} \cdot{ }^{27}$ Furthermore, the peak intensity of $\mathrm{MAPbI}_{3}$ is stronger with the solution concentration increasing, and the 0.4-prefilm show the highest peak. It may be ascribed to the amount or the crystallinity of $\mathrm{MAPbI}_{3}$ enhancement. After the formation of x-prepared film, the $\mathrm{PbI}_{2}$ solution was spin-coated on it, and $\mathrm{MAPbI}_{3}$ is resolved into $\mathrm{PbI}_{2}$ and MAI. ${ }^{28}$ In Fig $2 \mathrm{~b}$, there is no $\mathrm{MAPbI}_{3}$ peak any more, leaving the $\mathrm{PbI}_{2}$ peak exists, and $\mathrm{PbI}_{2}-0.2$ prefilm has the highest peak intensity. But it is hard to detect the trace amount of MAI through XRD characterization. In Fig 2c, beside $\mathrm{MAPbI}_{3}$ (110) peak mentioned above, other diffraction peaks at $20.48^{\circ}, 23.46^{\circ}$, $24.47^{\circ}, 28.40^{\circ}, 31.86^{\circ}, 40.49^{\circ}$ and $43.19^{\circ}$ can be assigned to (112), (211), (202), (220), (310), (224) and (314) diffractions respectively. All the samples show the same pattern positions, which is in agreement with previously reported $\mathrm{MAPbI}_{3}$ in literature. ${ }^{26}$ It is noteworthy that there is less $\mathrm{PbI}_{2}$ exist in the pre-treated sample compared with the $\mathrm{MAPbI}_{3}-0$ prefilm, which is observed in the XRD pattern, indicating that the residual $\mathrm{MAI}$ in $\mathrm{PbI}_{2}$-xprefilm facilitate the conversion of inner $\mathrm{PbI}_{2}$ to $\mathrm{MAPbI}_{3}$. In addition, the high crystalline of $\mathrm{MAPbI}_{3}$ in $\mathrm{MAPbI}_{3}-0.2$ prefilm is beneficial to the photovoltaic performance in perovskite solar cell.

In order to figure out the function of tiny $\mathrm{PbI}_{2}$ in perovskite solar cell, an illustration on the correlation between the morphology and the energy band gap diagram of the $\mathrm{PbI}_{2} /$ perovskite film is demonstrated in Fig. 3d. In the path 1, the bottom $\mathrm{PbI}_{2}$ block 
the electron injection from perovskite to $\mathrm{TiO}_{2}$, as the conduction band of $\mathrm{PbI}_{2}$ is located higher than that of the perovskite. But in the path 2 and 3, the remnant $\mathrm{PbI}_{2}$ acts as a blocking layer between the $\mathrm{TiO}_{2}$ semiconductor and the perovskite, reducing the probability of back electron transfer (charge recombination). Synthetically balance the double-edged effect of $\mathrm{PbI}_{2}$, it is necessary to control the trace amount $\mathrm{PbI}_{2}$ in order to improve perovskite solar cell device performance. ${ }^{17}$

To avoid batch-to-batch variations in the photocurrent, cells were assembled in the same batch ( 8 devices), and the $\mathrm{TiO}_{2}$-coated films were selected at random before spin-coating by the solutions. Fig. 4 presents the typical J-V characteristics of perovskite solar cells based on different $\mathrm{MAPbI}_{3}-\mathrm{xprefilm}$. The solar cell performance parameters extracted from the data are presented in Table 1 . The $\mathrm{MAPbI}_{3}-0$ prefilm -based cell exhibits a short-circuit photocurrent density $\left(\mathrm{J}_{\mathrm{SC}}\right)$ of $17.65 \mathrm{~mA} \mathrm{~cm}$, open-circuit voltage $\left(\mathrm{V}_{\mathrm{OC}}\right)$ of $0.94 \mathrm{~V}$, and fill factor $(\mathrm{FF})$ of $54.3 \%$, yielding a power conversion efficiency of $9.11 \%$. Through the addition of the 0.1 -prefilm pre-treatment, the improved PCE of $10.08 \%$ is obtained. Surprisingly, the highest PCE of $11.06 \%$ is acquired based on the $\mathrm{MAPbI}_{3}-0.2$ prefilm, by adjusting the amount of residual $\mathrm{PbI}_{2}$ and the morphology of $\mathrm{MAPbI}_{3}$. Considering the similar FF and $\mathrm{V}_{\mathrm{OC}}$ values in the samples of $\mathrm{MAPbI}_{3}-0.2$ prefilm and $\mathrm{MAPbI}_{3}-0$ prefilm, the efficiency enhancement was mainly contributed by the higher $\mathrm{J}_{\mathrm{SC}}$. The $\mathrm{J}_{\mathrm{SC}}$ for $\mathrm{MAPbI}_{3}-0.2$ prefilm increases to $20.08 \mathrm{~mA} \mathrm{~cm}{ }^{-2}$, which was due to the smooth morphology and trace amount of $\mathrm{PbI}_{2}$ verified by above results. Furthermore, the stronger light absorption discussed below benefits the extension of $\mathrm{J}_{\mathrm{SC}}$. Nevertheless, with the pre-treated mixed solution beyond $0.2 \mathrm{M}$, the decrease of $\mathrm{J}_{\mathrm{SC}}, \mathrm{V}_{\mathrm{OC}}$, and $\mathrm{FF}$ lead to the device performance deterioration, and the main reason is due to the poor coverage of perovskite film. It is reported that photovoltaic performance was found to be strongly dependent on perovskite layer coverage. $^{29}$ As a result, the PCE drops to $6.46 \%$ for $\mathrm{MAPbI}_{3}-0.3$ prefilm and $4.30 \%$ for $\mathrm{MAPbI}_{3}-0.4$ prefilm. The averaged photovoltaic parameters extracted from $\mathrm{J}-\mathrm{V}$ curves are collected in Figure $\mathrm{S} 3, \mathrm{~V}_{\mathrm{OC}}, \mathrm{J}_{\mathrm{SC}}, \mathrm{FF}$ and efficiency exhibit the similar tendency on $\mathrm{x}$ value in the $\mathrm{MAPI}_{3}$-xprefilm. From the $\mathrm{J}-\mathrm{V}$ curves of various cells described above, the photocurrent is the most important 
factor to the perovskite solar cell performance. To further understand the origin of this phenomenon, a series of optical absorption and photocurrent spectroscopic studies have been carried out. Fig. 5a shows the absorptance spectra measured with an integrating sphere for the five devices. All the films show absorption onsets at $800 \mathrm{~nm}$ with broad absorption ranging from the visible to near-IR region. In the whole visible region, the $\mathrm{MAPbI}_{3}-0.2$ prefilm exhibits the higher optical absorption ability, contributing to more light-generated electron and larger current density, compared with other devices. It may result from the better crystallinity of perovskite and smoother surface film, which has been discussed above. For the samples of $\mathrm{MAPbI}_{3}$-xprefilm ( $\left.\mathrm{x}=0,0.1,0.2\right)$, the absorption cures display a similar trend. For example, as for $\mathrm{MAPbI}_{3}-0.2$ prefilm, the film harvests more than $93 \%$ of the incident photons between 420 and $650 \mathrm{~nm}$. However, beyond $650 \mathrm{~nm}$, the light-harvesting efficiency of the film decreases gradually and then drops sharply to zero near the band gap of the perovskite, which is consistent with Pellet's report. ${ }^{30}$ For $\mathrm{MAPbI}_{3}-0.3$ prefilm, it is noteworthy that the absorbance above $650 \mathrm{~nm}$ was much higher than the previous three samples, which might be ascribed from low coverage and surface scattering of $\mathrm{MAPbI}_{3}$ film. ${ }^{19}$ Moreover, the absorbance between 420 and $650 \mathrm{~nm}$ was lower than that of $\mathrm{MAPbI}_{3}-0.1$ prefilm and $\mathrm{MAPbI}_{3}-0.2$ prefilm, manifesting the smaller current density generated in $\mathrm{MAPbI}_{3}-0.3$ prefilm.

In addition, the steady-state photoluminescence (PL) measurement was conducted to investigate the recombination of the photo-generated electron. All the samples emission peaks are located at $770 \mathrm{~nm}$ (excitation wavelength: $460 \mathrm{~nm}$ ) and consistent with previous reports of emission from $\mathrm{MAPbI}_{3} .{ }^{31}$ However, the perovskite PL quantum yield of the $\mathrm{MAPbI}_{3}-0.2$ prefilm is largely reduced compared to that of theMAPbI ${ }_{3}-0$ prefilm, demonstrating an enhanced charge carrier extraction and reduced recombination. ${ }^{32}$ The thickness reduction of perovskite film and lower amount of residual $\mathrm{PbI}_{2}$ before mentioned may lead to the decreased intensity of PL spectra. The poor performance of $\mathrm{MAPbI}_{3}-0.4$ prefilm is proved by the $\mathrm{PL}$ curve, where an intensively sharp peak appears at $770 \mathrm{~nm}$. The high recombination is ascribed from the low coverage of perovskite film. 


\section{Conclusions}

In summary, a facial and modified sequential spin-coating deposition of $\mathrm{CH}_{3} \mathrm{NH}_{3} \mathrm{PbI}_{3}$ $\left(\mathrm{MAPbI}_{3}\right)$ absorber on mesoporous $\mathrm{TiO}_{2}$ films was developed. The $\mathrm{MAPbI}_{3}$ and $\mathrm{PbI}_{2}$ compound pre-treated film was firstly formed by dipping different concentrations of DMF precursor solution containing $\mathrm{PbI}_{2}$ and MAI before the two-step procedure. Then, the $\mathrm{MAPbI}_{3}$ was dissolved to $\mathrm{PbI}_{2}$ and tiny MAI through dipping a $\mathrm{PbI}_{2}$ solution on the pre-treated film and the tiny reserved MAI facilitate the inner $\mathrm{PbI}_{2}$ transforming to $\mathrm{MAPbI}_{3}$. Finally, the high-crystalline $\mathrm{MAPbI}_{3}$ with trace remnant $\mathrm{PbI}_{2}$ was obtained by loading MAI solution. In view of the surface roughness and coverage of the $\mathrm{MAPbI}_{3}$, the optimal concentration of precursor solution was obtained. Compared with $\mathrm{MAPbI}_{3}-0$ prefilms, the efficiency boosted from $9.11 \%$ to $11.16 \%$ based on $\mathrm{MAPbI}_{3}-0.2$ prefilms device. The improved device performance was mainly attributed to increasing $\mathrm{J}_{\mathrm{SC}}$, which should be the result of smoother surface morphology, less remained $\mathrm{PbI}_{2}$, higher light absorption, and lower recombination. This method opened up a new pathway for further improvement of device performance of perovskite solar cell fabricated by sequential spin-coating deposition.

\section{Acknowledgement}

The authors gratefully acknowledge the financial support of the National Science Foundation of China (No.51202112), A Project Funded by the Priority Academic

Program Development of Jiangsu Higher Education Institutions, the Jiangsu Innovation Program for Graduate Education (KYLX-0261), Foundation of Graduate Innovation Centre in NUAA (kfjj201442), the Fundamental Research Funds for the Central Universities, Open Fund of Jiangsu Key Laboratory of Materials and Technology for Energy Conversion (No. MTEC-2015M04), and the Fundamental Research Funds for the Central Universities (No. 20150027). 


\section{References}

[1] J.H. Noh, S.H. Im, J.H. Heo, T.N. Mandal, S. Seok, Chemical management for colorful, efficient, and stable inorganic-organic hybrid nanostructured solar cells, Nano Lett. 13 (2013) 1764-1769.

[2] N.G. Park, Organometal perovskite light absorbers toward a 20\% efficiency low-cost solid-state mesoscopic solar cell, J. Phys. Chem. Lett. 4 (2013) 2423-2429.

[3] S.D. Stranks, G.E. Eperon, G. Grancini, C. Menelaou, M.J.P. Alcocer, T. Leijtens, L.M. Herz, A. Petrozza, H.J. Snaith, Electron-hole diffusion lengths exceeding 1 micrometer in an organometaltrihalide perovskite absorber, Science 342 (2013) $341-344$

[4] Kojima, K. Teshima, Y. Shirai, T. Miyasaka, Organometal halide perovskites as visible-light sensitizers for photovoltaic cells, J. Am. Chem. Soc. 131 (2009) $6050-6051$.

[5] P. Gao, M. Grätzel, M.K, Organohalide lead perovskites for photovoltaic applications, Energy Environ. Sci. 7 (2014) 2448-2463.

[6] H.S. Kim, C.R. Lee, J.H Im, K.B. Lee, T. Moehl, A. Marchioro, S.J. Moon, R. Humphry-Baker, J.H. Yum, J.E. Moser, M, Grätzel, N.G. Park, Long-range balanced electron-and hole-transport lengths in organic-inorganic $\mathrm{CH}_{3} \mathrm{NH}_{3} \mathrm{PbI}_{3}$, Science 342 (2013) 344-347.

[7] F. Hao, C. C. Stoumpos, D. H. Cao, R. P. H. Chang, M.G. Kanatzidis, Lead-free solid-state organic-inorganic halide perovskite solar cells, Nat. Photonics 8 (2014), 489-494.

[8] Y. Ogomi, A. Morita, S.Tsukamoto, T. Saitho, N. Fujikawa, Q. Shen, T. Toyoda, K. Yoshino, S.S. Pandey, T. Ma, S. Hayase, $\mathrm{CH}_{3} \mathrm{NH}_{3} \mathrm{Sn}$ x $\mathrm{Pb}(1-\mathrm{x}) \mathrm{I}_{3}$ Perovskite Solar Cells Covering up to 1060 nm, J. Phys. Chem. Lett. 5 (2014) 1004-1011.

[9] P. Schulz, E. Edri, S. Kirmayer, G. Hodes, D. Cahenb, A. Kahn, Interface energetics in organo-metal halide perovskite-based photovoltaic cells, Energy Environ. Sci. 7 (2014) 1377-1381.

[10]C.S. Ponseca, Jr, T. J. Savenije, M. Abdellah, K. Zheng, A. Yartsev, T. Pascher, T. 
Harlang, P. Chabera, T.Pullerits, A. Stepanov, J.P.Wolf, V. Sundström, Organometal halide perovskite solar cell materials rationalized: ultrafast charge generation, high and microsecond-long balanced mobilities, and slow recombination, J. Am. Chem. Soc. 136 (2014) 5189-5192.

[11]J. Burschka, N. Pellet, S.-J. Moon, R. Humphry-Baker1, P. Gao, M.K. Nazeeruddin, M. Grätzel, Sequential deposition as a route to high-performance perovskite-sensitized solar cells, Nature, 499 (2013) 316-319.

[12]J.H. Im, I.H. Jang, N. Pellet, M. Grätzel, N.G. Park, Growth of $\mathrm{CH}_{3} \mathrm{NH}_{3} \mathrm{PbI}_{3}$ cuboids with controlled size for high-efficiency perovskite solar cells, Nat. Nanotech. 9 (2014) 927-932.

[13]M.Z. Liu, M. B. Johnston, H.J. Snaith, Efficient planar heterojunction perovskite solar cells by vapour deposition, Nature 501 (2013) 395-398.

[14]Q. Chen, H. Zhou, Z. Hong, S. Luo, H.S. Duan, H.H. Wang, Y. Liu, G. Li, Y. Yang, Planar heterojunction perovskite solar cells via vapor-assisted solution process, J. Am. Chem. Soc.136 (2013) 622-625.

[15]Y.X. Zhao, K. Zhu, Solution Chemistry Engineering toward High-Efficiency Perovskite Solar Cells, J. Phys. Chem. Lett. 5 (2014) 4175-4186.

[16]Y.H. Lee, J. Luo, R. Humphry-Baker, P. Gao, M. Grätzel, M. K.Nazeeruddin, Unravelling the Reasons for Efficiency Loss in Perovskite Solar Cells, Adv.Funct.Mater. 2015 3925-3933

[17]D.H. Cao, C.C. Stoumpos, C.D. Malliakas, M.J. Katz, O.K. Farha, J.T. Huppand, M.G. Kanatzidis, Remnant $\mathrm{PbI}_{2}$, an unforeseen necessity in high-efficiency hybrid perovskite-based solar cells, APL Mat. 2(2014) 091101.

[18]Y. Zhao, J. Liu, X. Lu, Y. Gao, X. You, X. Xu, Improving the Efficiency of Perovskite Solar Cells through Optimization of the $\mathrm{CH}_{3} \mathrm{NH}_{3} \mathrm{PbI}_{3}$ Film Growth in Solution Process Method, Appl. Surf. Sci., 2015, doi:10.1016/j.apsusc.2015.10.132.

[19] Y. Xie, F. Shao, Y. Wang, T. Xu, D. Wang, F. Huang, Enhanced Performance of Perovskite $\mathrm{CH}_{3} \mathrm{NH}_{3} \mathrm{PbI}_{3}$ Solar Cell by Using $\mathrm{CH}_{3} \mathrm{NH}_{3} \mathrm{I}$ as Additive in Sequential Deposition, Appl. Mater. Interfaces 7 (2015) 12937-12942. 
[20]P. Docampo, J M. Ball, M. Darwich, G E. Eperon, H J. Snaith, Efficient organometal trihalide perovskite planar-heterojunction solar cells on flexible polymer substrates, Nat. Commun. 4 (2013) 2761-2767.

[21]S. Ito, S. Tanaka, H.Nishino, Lead-Halide Perovskite Solar Cells by $\mathrm{CH}_{3} \mathrm{NH}_{3} \mathrm{I}$ Dripping on $\mathrm{PbI}_{2}-\mathrm{CH}_{3} \mathrm{NH}_{3} \mathrm{I}-\mathrm{DMSO}$ Precursor Layer for Planar and Porous Structures Using CuSCN Hole-Transporting Material, J. Phys. Chem. Lett. 6 (2015) 881-886.

[22] J. Mao, H. Zhang, H. He, H. Lu, F. Xie, D. Zhang, K.S. Wong, W.C. H. Choy, Smooth $\mathrm{CH}_{3} \mathrm{NH}_{3} \mathrm{PbI}_{3}$ from controlled solid-gas reaction for photovoltaic applications, RSC Adv. 5 (2015) 73760-73766.

[23] G.C. Xing, N. Mathews, S.Y Sun, S.S Lim, Y.M. Lam, M. Grätzel, S. Mhaisalkar, T.C. Sum, Long-range balanced electron-and hole-transport lengths in organic-inorganic $\mathrm{CH}_{3} \mathrm{NH}_{3} \mathrm{PbI}_{3}$, Science 342 (2013) 344-347.

[24]N. Li, H.P Dong, H. Dong, J.L. Li, W.Z. Li, G.D Niu, X.D. Guo, Z.X. Wu and L.D.Wang, Multifunctional perovskite capping layers in hybrid solar cells, J. Mater. Chem. A 2 (2014) 14973-14978.

[25] G.E. Eperon, V.M. Burlakov, P. Docampo, A. Goriely, H.J. Snaith, Morphological Control for High Performance, Solution-Processed Planar Heterojunction Perovskite Solar Cells, Adv. Funct. Mater. 24 (2014) 151-157.

[26]H. Hu, D. Wang, Y. Zhou, J. Zhang, S. Lv, S. Pang, X. Chen, Z. Liu, N.P. Padture , G.L. Cui, Vapour-based processing of hole-conductor-free $\mathrm{CH}_{3} \mathrm{NH}_{3} \mathrm{PbI}_{3}$ perovskite/C60 fullerene planar solar cells, RSC Adv. 4 (2014) 28964-28967.

[27]H. Hu, D. Wang, Y. Zhou, J. Zhang, S. Lv, S. Pang, X. Chen, Z. Liu, N.P. Padture, G.L. Cui, $\mathrm{PbI}_{2}$-Based Dipping-Controlled Material Conversion for Compact Layer Free Perovskite Solar Cells, ACS Appl. Mater. Interfaces 7 (2015) 18156-18162.

[28]Leguy, Y. Hu, M.C.Quiles, M.I. Alonso, O.J. Weber, P. Azarhoosh, M. vanSchilfgaarde, M.T. Weller, T. Bein, J. Nelson, P. Docampo, P.R.F. Barnes, Reversible Hydration of $\mathrm{CH}_{3} \mathrm{NH}_{3} \mathrm{PbI}_{3}$ in Films, Single Crystals, and Solar Cells, Chem. Mater. 27 (2015) 3397-3407. 
[29]P.W. Liang, C.Y. Liao, C.C. Chueh, F. Zuo, S.T. Williams, X.K. Xin, J. Lin, A.K.Y. Jen, Additive enhanced crystallization of solution-processed perovskite for highly efficient planar-heterojunction solar cells, Adv. Mater. 26 (2014) 3748-3754.

[30]N. Pellet, P. Gao, G. Gregori, T.Y. Yang, M.K. Nazeeruddin, J. Maier, M. Grätzel, Mixed-Organic-Cation Perovskite Photovoltaics for Enhanced Solar-Light Harvesting, Angew. Chem. Int. Edit. 53 (2014) 3151-3157.

[31]J. Shi, Y. Luo, H. Wei, J. Luo, J. Dong, S. Lv, J. Xiao, Y. Xu, L. Zhu, X. Xu, H. Wu, D. Li, Q. Meng, Modified two-step deposition method for high-efficiency $\mathrm{TiO}_{2} / \mathrm{CH}_{3} \mathrm{NH}_{3} \mathrm{PbI}_{3}$ heterojunction solar cells, ACS Appl. Mater. Interfaces 6 (2014) 9711-9718.

[32]G. Zhu, T. Lin, X. Lü, W. Zhao, C. Yang, Z. Wang, H. Yin, Z. Liu, F. Huang, J. Lin, Black brookitetitania with high solar absorption and excellent photocatalytic performance, J. Mater. Chem. A 1 (2013) 9650-9653. 


\section{Tables}

Table 1 Summary of $\mathrm{MAPI}_{3}$-xprefilm-based solar cell performance parameters with varying $\mathrm{x}$ values $(\mathrm{x}=0-0.4)$.

\begin{tabular}{ccccc}
\hline Sample & $\begin{array}{c}\mathrm{V}_{\mathrm{OC}} \\
(\mathrm{V})\end{array}$ & $\begin{array}{c}\mathrm{J}_{\mathrm{SC}} \\
\left(\mathrm{mA} \mathrm{cm}^{-2}\right)\end{array}$ & $\begin{array}{c}\mathrm{FF} \\
(\%)\end{array}$ & $\begin{array}{c}\mathrm{PCE} \\
(\%)\end{array}$ \\
\hline $\begin{array}{c}\mathrm{MAPbI}_{3} \text {-0prefil } \\
\mathrm{m}\end{array}$ & 0.94 & 17.65 & 54.3 & 9.11 \\
$\begin{array}{c}\mathrm{MAPbI}_{3}-0.1 \text { prefi } \\
\text { lm }\end{array}$ & 0.94 & 18.68 & 56.9 & 10.08 \\
$\begin{array}{c}\mathrm{MAPbI}_{3}-0.2 \text { prefi } \\
\mathrm{lm}^{\mathrm{MAPbI}_{3}-0.3 \text { prefi }}\end{array}$ & 0.97 & 20.08 & 56.8 & 11.16 \\
$\begin{array}{c}\mathrm{lm}_{\mathrm{MAPbI}}-0.4 \text { prefi } \\
\text { lm }\end{array}$ & 0.87 & 15.06 & 49.5 & 6.46 \\
\hline
\end{tabular}




\section{Figures}

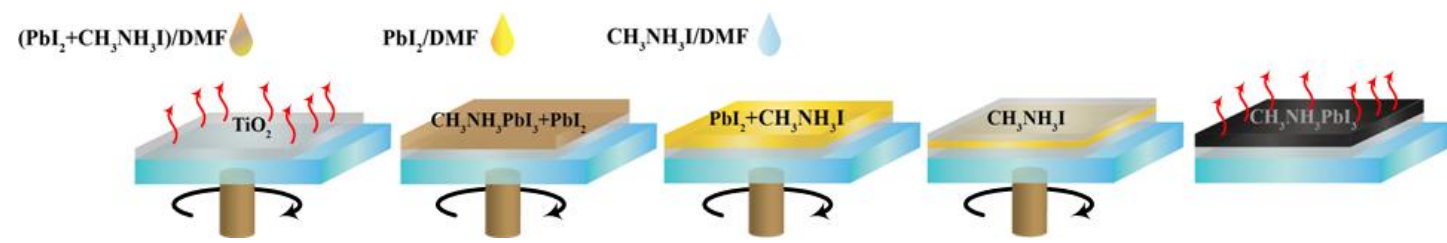

Fig. 1 Schematic illustration of modified two-step spin-coating procedure for $\mathrm{MAPbI}_{3}$ perovskite thin films. 

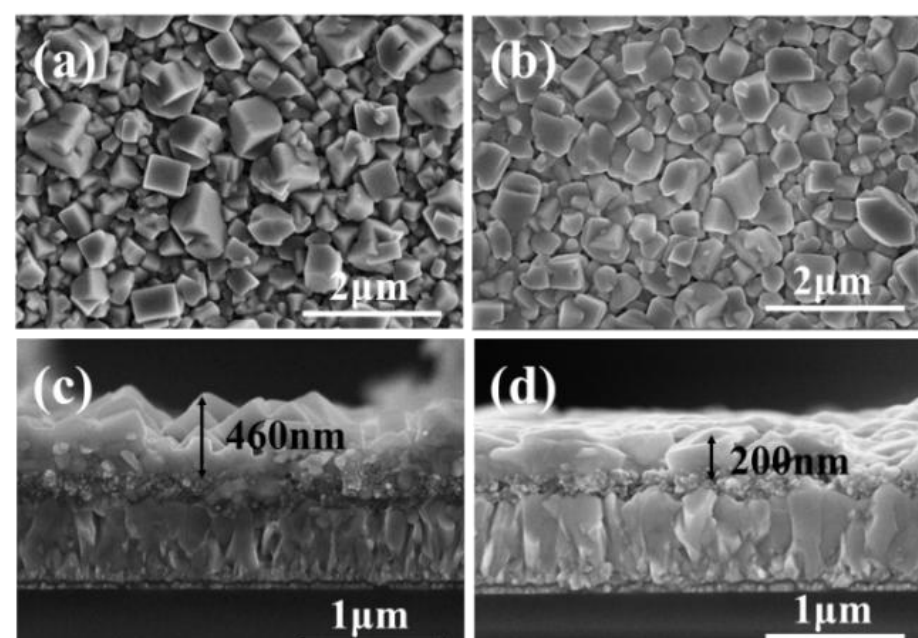

\section{(d)}
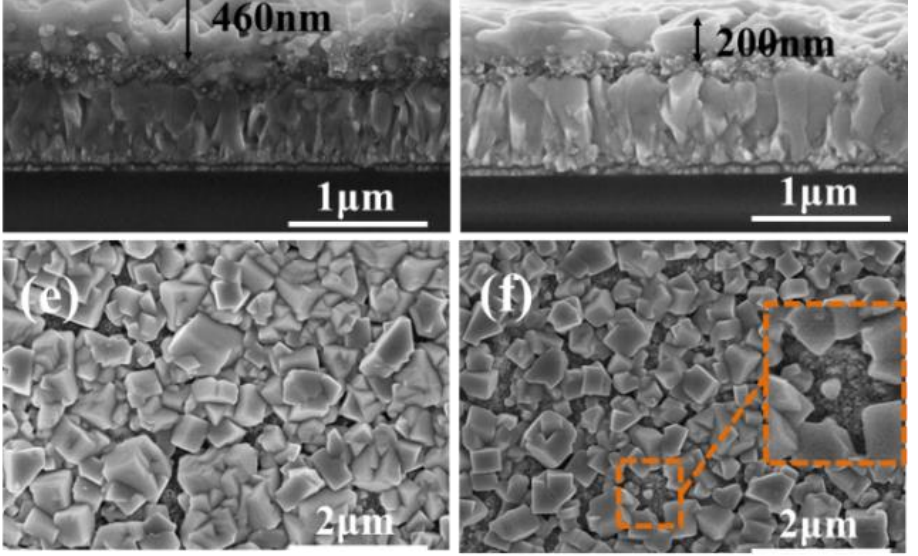

Fig. 2 Top view FE-SEM images of (a) $\mathrm{MAPbI}_{3}-0$ prefilm, (b) MAPbI $3-0.2$ prefilm, (e) $\mathrm{MAPbI}_{3}-0.3$ prefilm, (f) $\mathrm{MAPbI}_{3}-0.4$ prefilm and cross-sectional FE-SEM image of (c) $\mathrm{MAPbI}_{3}-0$ prefilm, (d) $\mathrm{MAPbI}_{3}-0.2$ prefilm. 

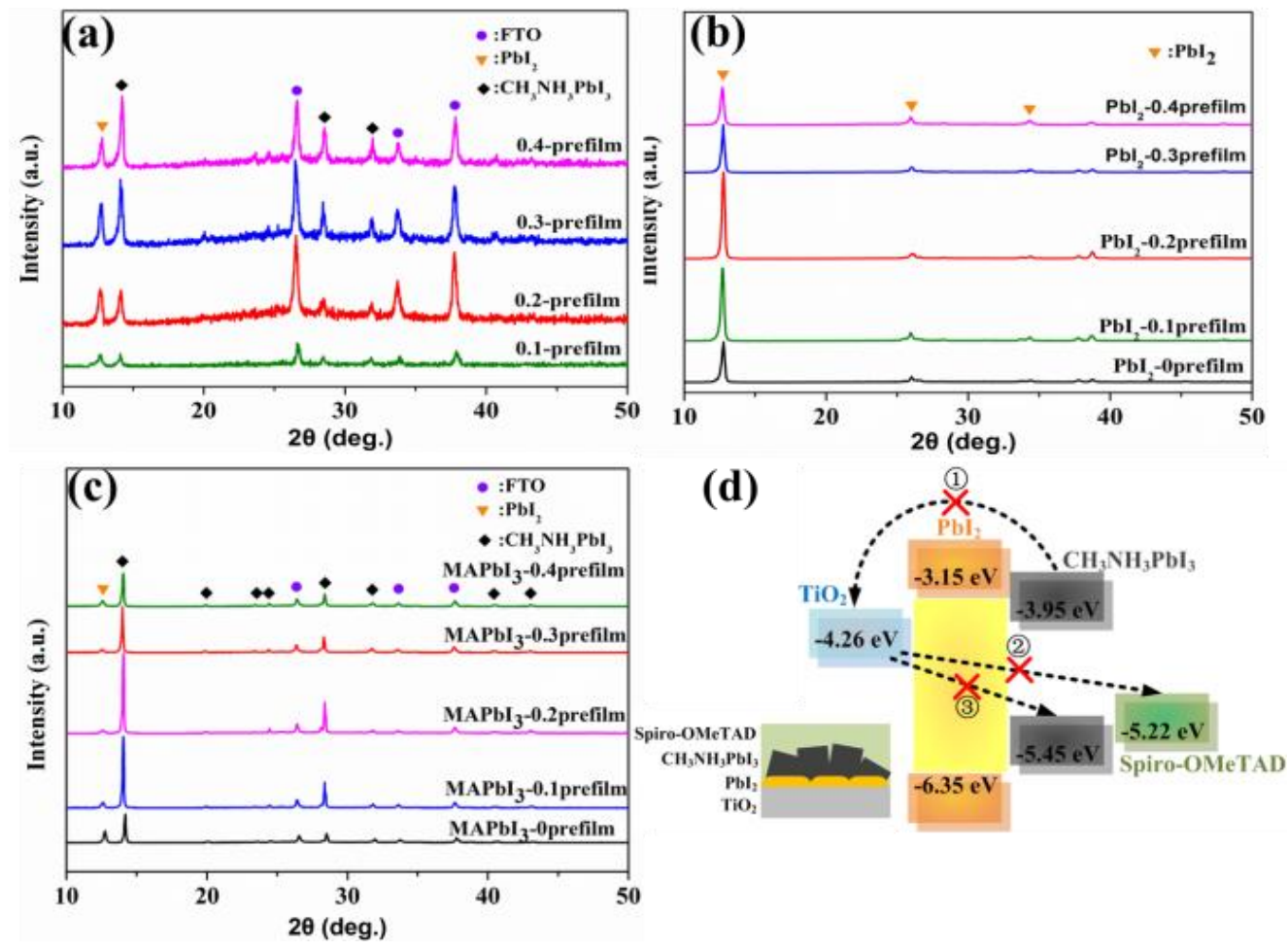

Fig. 3 (a-c) XRD spectra of $\mathrm{x}$-prefilm, $\mathrm{PbI}_{2}$-xprefilm, and $\mathrm{MAPbI}_{3}$-xprefilm as a function of $\mathrm{x}$ value $(\mathrm{x}=0-0.4)$; (d) model of the place of residual $\mathrm{PbI}_{2}$ exits in the solar cell and the charge-injection/recombination retardation by the unconverted $\mathrm{PbI}_{2}{ }^{16-17}$ 


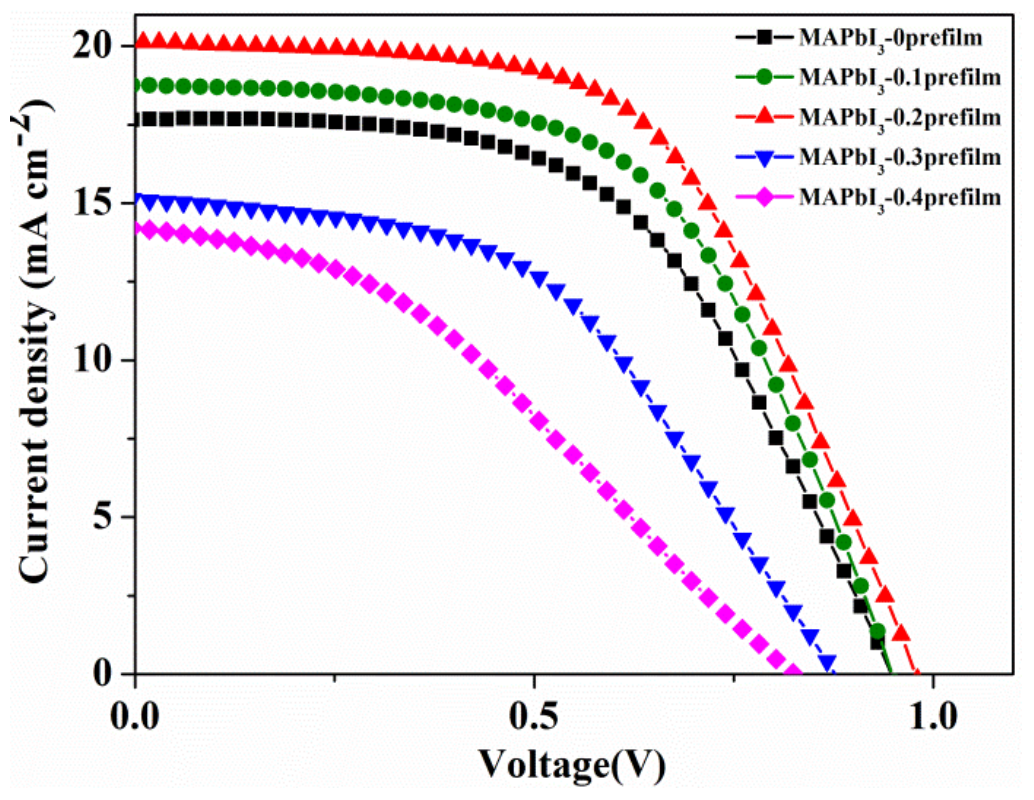

Fig .4 Current-voltage $(\mathrm{J}-\mathrm{V})$ curve of the $\mathrm{MAPI}_{3}$-xprefilm-based $(\mathrm{x}=0-0.4)$ solar cell under a standard AM 1.5 solar illumination at an intensity of $100 \mathrm{~mW}$ $\mathrm{cm}^{2}$. 

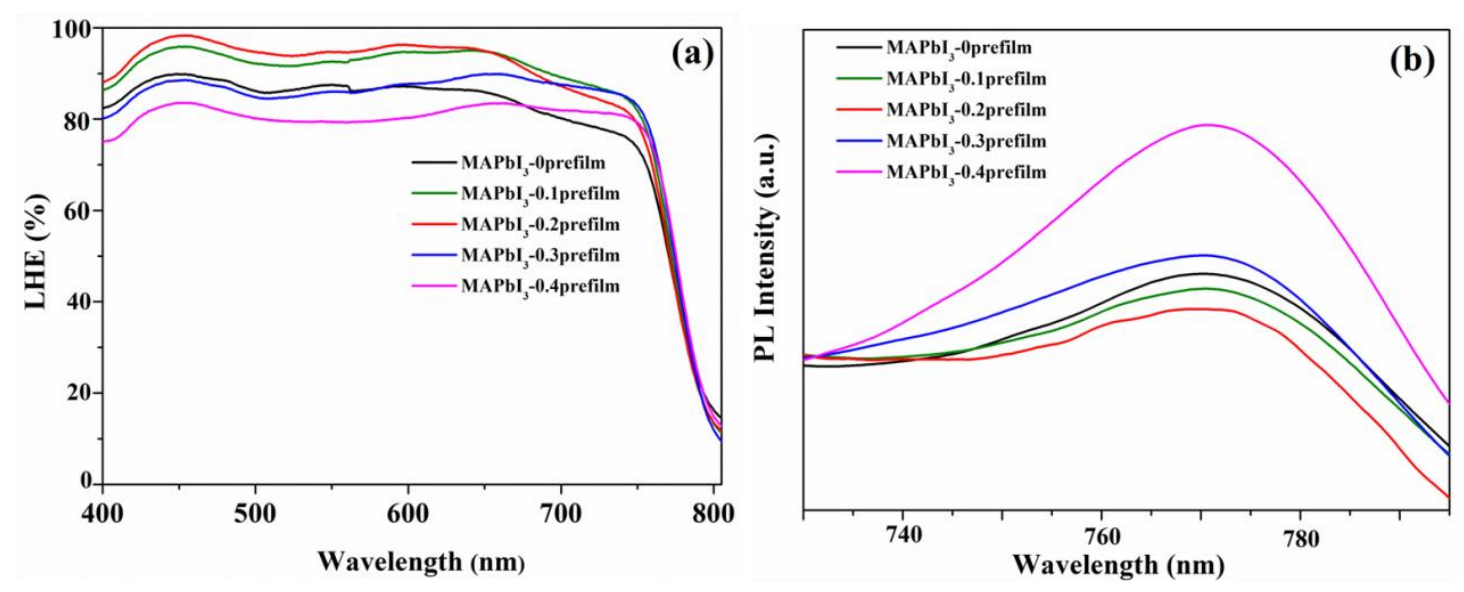

Fig. 5 (a) Light-harvesting efficiency, (b) Steady-state PL spectra for $\mathrm{MAPI}_{3}$-xprefilm with varying $\mathrm{x}$ value $(\mathrm{x}=0-0.4)$. 